\title{
Cardiovascular and thermal strain during 3-4 days of a metabolically demanding cold-weather military operation
}

\author{
John W. Castellani ${ }^{1 *}$, Marissa G. Spitz ${ }^{1}$, Anthony J. Karis ${ }^{1}$, Svein Martini², Andrew J. Young ${ }^{1}$, Lee M. Margolis ${ }^{1}$, \\ J. Phillip Karl ${ }^{1}$, Nancy E. Murphy' ${ }^{1}$ Xiaojiang Xu' ${ }^{1}$, Scott J. Montain' ${ }^{1}$, Jamie A. Bohn ${ }^{1}$, Hilde K. Teien², \\ Pål H. Stenberg ${ }^{3}$, Yngvar Gundersen ${ }^{2}$ and Stefan M. Pasiakos ${ }^{1}$
}

\begin{abstract}
Background: Cardiovascular (CV) and thermal responses to metabolically demanding multi-day military operations in extreme cold-weather environments are not well described. Characterization of these operations will provide greater insights into possible performance capabilities and cold injury risk.

Methods: Soldiers from two cold-weather field training exercises (FTX) were studied during 3-day (study 1 , $n=18$, age: $20 \pm 1$ year, height: $182 \pm 7 \mathrm{~cm}$, mass: $82 \pm 9 \mathrm{~kg}$ ) and 4-day (study $2, n=10$, age: $20 \pm 1$ year, height: $182 \pm 6 \mathrm{~cm}$, mass: $80.7 \pm 8.3 \mathrm{~kg}$ ) ski marches in the Arctic. Ambient temperature ranged from -18 to $-4^{\circ} \mathrm{C}$ during both studies. Total daily energy expenditure (TDEE, from doubly labeled water), heart rate (HR), deep body ( $T_{\text {pill }}$ ), and torso $\left(T_{\text {torso }}\right)$ skin temperature (obtained in studies 1 and 2$)$ as well as finger $\left(T_{\text {fing }}\right)$, toe $\left(T_{\text {toe }}\right)$, wrist, and calf temperatures (study 2) were measured.

Results: TDEE was $6821 \pm 578 \mathrm{kcal} \mathrm{day}^{-1}$ and $6394 \pm 544$ for study 1 and study 2, respectively. Mean HR ranged from 120 to $140 \mathrm{bpm}$ and mean $T_{\text {pill }}$ ranged between 37.5 and $38.0^{\circ} \mathrm{C}$ during skiing in both studies. At rest, mean $T_{\text {pill }}$ ranged from 36.0 to $36.5^{\circ} \mathrm{C}$, (lowest value recorded was $35.5^{\circ} \mathrm{C}$ ). Mean $T_{\text {fing }}$ ranged from 32 to $35^{\circ} \mathrm{C}$ during exercise and dropped to $15^{\circ} \mathrm{C}$ during rest, with some $T_{\text {fing }}$ values as low as $6-10^{\circ} \mathrm{C} . T_{\text {toe }}$ was above $30^{\circ} \mathrm{C}$ during skiing but dropped to $15-20^{\circ} \mathrm{C}$ during rest.
\end{abstract}

Conclusions: Daily energy expenditures were among the highest observed for a military training exercise, with moderate exercise intensity levels ( $65 \%$ age-predicted maximal HR) observed. The short-term cold-weather training did not elicit high $C V$ and $T_{\text {pill }}$ strain. $T_{\text {fing }}$ and $T_{\text {toe }}$ were also well maintained while skiing, but decreased to values associated with thermal discomfort at rest.

Keywords: Deep body temperature, Finger temperature, Heart rate, IREQ, Thermal modeling

\section{Background}

Warfighters can expend more energy ( 10-40\%) during cold-weather operations due to heavy clothing, carrying extra weight, and the effort to work/walk/ski in snow and difficult terrain [1-3]. This may accelerate the development of fatigue, reducing operational effectiveness and

\footnotetext{
${ }^{*}$ Correspondence: john.w.castellani.civ@mail.mil

1 United States Army Research Institute of Environmental Medicine,

10 General Greene Avenue, Bldg 42, Natick, MA 01760, USA

Full list of author information is available at the end of the article
}

performance [4]. Exercising in the cold to fatigue can also lead to thermal strain, as evidenced by a decline in core temperature [5-7]. Furthermore, cold-weather operations may reduce peripheral toe and finger skin temperatures $[8,9]$, primarily after stopping work, increasing susceptibility to cold injury and decreasing dexterity and tactile sensation.

Higher exercise intensities can lower thermal strain in the cold by causing higher deep body and peripheral temperatures. Laboratory studies clearly demonstrate this in cold-wet $[10,11]$ and cold-dry [12] conditions. Similar 
findings are observed in field and occupational settings $[9,13,14]$. For example, during light, moderate, and heavy exercise intensities over 6-h work days [13], rectal temperature was lowest during light work $(\sim 275 \mathrm{~W})$ and highest during work eliciting $\sim 435 \mathrm{~W}$ and finger $\left(T_{\text {fing }}\right)$ and toe $\left(T_{\text {toe }}\right)$ temperatures followed the same pattern. These field studies cited were conducted during limited cold exposure, that is, exposure durations less than 6 to $8 \mathrm{~h}$ over a 24-h period with access to heated shelter when not working. Similarly, adventure sporting events (e.g., Iditarod Trail Invitational, 6633 Ultra), can take place over multiple days under extreme environmental conditions where participants self-select their exercise intensity. Furthermore, these military and sporting scenarios often have multiple exacerbating physiological stressors, including very high energy expenditures and energy deficits [15]. This cumulative exposure to cold and other stressors may increase susceptibility to cold injuries [16], but the impact of multiple days of sub-freezing cold exposure during field training on cardiovascular and thermal strain during high deficits are not well described.

Cold-weather guidance and thermoregulatory models are available to determine the clothing insulation required (IREQ) during cold-weather work to maintain thermal balance $[17,18]$ and to predict deep body and skin temperatures during cold exposure (e.g., 6-cylinder (6-CTM) model developed by Xu et al. $[19,20]$ ). Although these models have been available for over two decades, validation studies have been limited. Previous occupational studies using the IREQ to determine if adequate clothing was used by workers and soldiers during cold exposure has only been studied over the course of one working day [21-23]. Thermoregulatory models for use in cold conditions have primarily been validated and tested during cold-water immersion $[24,25]$ and not during exercise in cold air.

The purpose of this study was to characterize the cardiovascular and thermal strain experienced by Soldiers with significant energy deficits participating in two winter military field-training exercises in the Norwegian Arctic [26, 27]. A secondary purpose was to determine the insulation required (IREQ) to maintain thermal balance during these winter exercises and determine, post hoc, if this level of insulation was sufficient for the multiple day winter exercise, as well as compare measured to predicted values using the 6-CTM. We hypothesized that cardiovascular strain would be moderate and that deep body thermal strain would not reach hypothermic levels due to proper clothing access and adherence to risk management strategies. We also hypothesized that the clothing required to maintain thermal balance during multiple days of Arctic ski marching would be adequate.

\section{Methods}

\section{Subjects and experimental design \\ Study 1}

Eighteen male Norwegian Soldiers [age: $20 \pm 1$ year, height: $182 \pm 7 \mathrm{~cm}$, mass: $82 \pm 9 \mathrm{~kg}$, (mean \pm SD)] volunteered after providing informed, written consent [26]. This study was approved by the Institutional Review Board at the US Army Research Institute of Environmental Medicine (Natick, MA, USA) and the Regional Committees for Medical and Health Research Ethics (Oslo, $\mathrm{NO}$ ).

The Soldiers participated in a 7-day winter training exercise that culminated with a 3-day 54-km crosscountry ski march in the Norwegian Arctic during mid-March. During the March, the volunteers skied in 50:10 min work-to-rest ratios for 6-10 h per day. Each volunteer carried/wore $\sim 45 \mathrm{~kg}$ of equipment throughout the ski march. The ski march pace was self-selected. At the end of each day, the Soldiers set up and slept in 10-man Arctic tents. Four Norwegian military coldweather rations, $\left(\sim 5100 \mathrm{kcal} \mathrm{day}^{-1}\right.$ if entirely consumed) were provided each day. Data are reported on the 3-day ski march portion of the training exercise only.

\section{Study 2}

Ten male Norwegian Soldiers (age: $20 \pm 1$ year, height: $182 \pm 6 \mathrm{~cm}$, mass: $80.7 \pm 8.3 \mathrm{~kg}$ ) volunteered for study 2 after providing informed, written consent. The volunteers in study 2 were a different cohort than the volunteers in study 1 . These Soldiers were a subset of the total number of Soldiers who volunteered for a larger study $(n=73,[27])$. This study was approved by the Institutional Review Board at the US Army Research Institute of Environmental Medicine (Natick, MA, USA) and the Regional Committees for Medical and Health Research Ethics (Oslo, NO).

Similar to study 1 , the Soldiers skied, self-paced, in 50:10 min work-to-rest ratios, while carrying a $45-\mathrm{kg}$ pack, over a total distance of $51 \mathrm{kM}$, in the Norwegian Arctic in late January. The Soldiers slept in one- to fourman tents and were responsible for digging and setting up their tent site. This study differed from study 1 with regard to food allocated to each volunteer as these volunteers received only three Norwegian cold-weather rations per day $\left(\sim 3500 \mathrm{kcal} \mathrm{day}^{-1}\right.$ if entirely consumed). The volunteers were further randomized to one of three feeding groups, protein (PRO) supplementation, carbohydrate $(\mathrm{CHO})$ supplementation, and control $(\mathrm{CON}$, no supplementation). In the $\mathrm{PRO}$ and $\mathrm{CHO}$ groups, the supplement provided an additional $1000 \mathrm{kcal} \mathrm{day}^{-1}$. Of the 10 volunteers in the thermal strain group, there were 5 in the CHO group, 2 in the PRO group, and 3 in the $\mathrm{CON}$ group. The data for these three feeding groups were 
pooled for the analyses reported in this paper as there were no differences for the groups.

\section{Measurements}

Volunteers wore a physiological monitoring system (PSM; Equivital-1, Hidalgo Ltd. Cambridge, UK) to measure heart rate (HR), chest skin temperature $\left(T_{\text {chest }}\right)$, and core temperature $\left(T_{\text {pill }}\right)$ in both studies. The HR and $T_{\text {chest }}$ sensors were imbedded within the chest strap and shoulder support of the PSM. Ingested temperature telemetry pills (Jonah ${ }^{\mathrm{TM}}$ Core Temperature Pill, Respironics, Bend OR) were used to obtain $T_{\text {pill }}$.

In study $2, \mathrm{HR}, T_{\text {chest }}$, and $T_{\text {pill }}$ were measured as in study 1 . Additional skin temperature measurements were obtained on the wrist (ventral, non-dominant hand), 3rd finger (nailbed), right gastrocnemius, and right 1st toe (nailbed). Wrist and calf temperatures were obtained using iButton data loggers (Dallas Semiconductor, Dallas, TX) affixed with Velcro straps; finger and toe temperatures were measured using thermistors affixed to the nailbed region using an adhesive and secondarily secured with medical grade tape.

Energy expenditure (EE) and energy intake (EI) were measured using doubly labeled water and subject selfreport of items eaten, respectively. These measurements and values are reported in detail elsewhere [26, 27]. Table 1 shows the EE, EI, and energy deficit for studies 1 $(n=17)$ and $2(n=9)$.

Weather data were obtained from the closest meteorological station to each training exercise by accessing the Norwegian Meteorological Institute website (http:// eklima.met.no). In study 1 , air temperatures ranged from -18 to $-6{ }^{\circ} \mathrm{C}$; wind speeds ranged from 5 to $13 \mathrm{~m} \mathrm{~s}^{-1}$; in study 2 , air temperatures ranged from -17 to $-3{ }^{\circ} \mathrm{C}$ and wind speeds ranged from 0.3 to $19 \mathrm{~m} \mathrm{~s}^{-1}$. These environmental conditions produced wind chill temperature index values as low as $-26{ }^{\circ} \mathrm{C}$ in study 1 and $-25{ }^{\circ} \mathrm{C}$ in study 2.

In both winter training exercises, the Soldiers wore the same uniform. Clothing insulation over the torso, arms, and legs was $\sim 2.75$ clo and consisted of a woolen mesh base undergarment, wool middle layer, and waterproof/windproof outer layer. Foot insulation, provided by a wool sock and cold-weather boot, was 1.76 clo. Thermal (Rt, $\mathrm{m}^{2} \mathrm{C} \mathrm{W}^{-1}$ ) and evaporative resistance (Re, $\mathrm{m}^{2} \mathrm{kPa} \mathrm{W}^{-1}$ ) was determined using a thermal manikin (TM) following the standard outlined in ASTM 1291-10. Briefly, the manikin mean skin temperature was set at $35^{\circ} \mathrm{C}$, with the ambient temperature and air velocity set at $23^{\circ} \mathrm{C}$ and $0.4 \mathrm{~m} \mathrm{~s}^{-1}$, respectively. The TM was dressed in the Norwegian military cold-weather uniform worn during the ski marches, consisting of a base, mid-, and outer layer.
Table 1 Energy expenditure, intake, and balance during study iterations \#1 and \#2

\begin{tabular}{|c|c|c|c|}
\hline & $\begin{array}{l}\text { Energy expendi- } \\
\text { ture }\end{array}$ & Energy intake & Energy balance \\
\hline Study $1(n=17)$ & $\begin{array}{c}6821 \pm 578 \\
(28.5 \pm 2.4)\end{array}$ & $\begin{array}{l}3465 \pm 622 \\
(14.5 \pm 2.6)\end{array}$ & $\begin{array}{c}-3357 \pm 691 \\
(-14.0 \pm 2.9)\end{array}$ \\
\hline Study $2(n=9)$ & $\begin{array}{l}6394 \pm 544 \\
(26.8 \pm 2.3)\end{array}$ & $\begin{array}{l}2714 \pm 799 \\
(11.4 \pm 3.3)\end{array}$ & $\begin{array}{c}-3782 \pm 1001 \\
(-15.8 \pm 4.2)\end{array}$ \\
\hline
\end{tabular}

Values (mean \pm S.D.) are in kcals and MJ (parenthetically)

The insulation required (IREQ) and duration limited exposure (DLE) during ski marching on day 2 of Study 2 were calculated (Lund University website-http://www. eat.lth.se) according to ISO 11079 [18] and based upon the work of Holmer [17]. The assumptions for calculating IREQ and DLE were as follows: predicted metabolic rate [28] for a walking speed of $0.66 \mathrm{~m} \mathrm{~s}^{-1}$, terrain coefficient of 1.7 , and external load of $50.9 \mathrm{~kg}$. This value for metabolic rate was increased by an additional $40 \%$ due to the layering effect of cold-weather clothing and the foot mass effect [29-32]. As well, mean air temperature and wind speed measured during the movement portion of Day 2 was input. Day 2 from study 2 was chosen for modeling since the day 1 movement was shorter in duration and a large storm came in on day 3 . As well, we did not obtain skinfold measurements during study 1 and thus could not estimate \% body fat.

We also determined the goodness of fit between observed temperatures (pill, chest, calf) and the 6-CTM $[19,33]$. The 6 -CTM model was derived from 2 previous thermoregulatory models [34, 35]. The 6-CTM describes the human body as a passive system of six cylinders: head, trunk, arms, legs, hands, and feet. Each cylinder is further concentrically divided into compartments representing the core, muscle, fat, and skin. Blood is represented as a one-loop circulatory system and is an independent compartment. Thus, the human body is represented by 25 compartments. The sizes of the compartments are determined from height, weight, and body fat percentage [19, 33]. The 6-CTM inputs include individual characteristics (i.e., height, weight, fat percentage, age, $\mathrm{VO}_{2 \max }$ ), predicted external workload [28] for walking at $0.66 \mathrm{~m} \mathrm{~s}^{-1}$ using a terrain coefficient of 1.7, and environmental (i.e., temperature, humidity, and wind velocity) and clothing (clothing insulation clo, moisture permeability index $i_{m}$ ) parameters for each of the six cylinders. The model used in this analysis uses a standard initial starting core temperature of $36.8^{\circ} \mathrm{C}$. For $T_{\text {pill }}$, we adjusted the model predictions by using changes in pill temperature rather than absolute temperatures so that we could compare between observed and predicted values. Comparisons (measured 
vs. predicted, respectively) were made between $T_{\text {pill }}$ and $T_{\text {core, }} T_{\text {chest }}$ and $T_{\text {torso }}$, and $T_{\text {calf }}$ and $T_{\text {leg }} . T_{\text {wrist }}$ was not compared to the model as there is no corresponding site in the 6-CTM.

\section{Statistical analysis}

Differences between observed temperatures and 6-CTM model predictions were evaluated by comparing the root mean square deviation (RMSD) of each trial with the observed standard deviation [36]. This statistic is used to quantitatively determine the goodness-of-fit between model predictions and observed data. The RMSD $\left({ }^{\circ} \mathrm{C}\right)$ is defined as

$$
\mathrm{RMSD}=\sqrt{\frac{1}{n}} \sum_{i=1}^{n} d_{i}^{2},
$$

where $d_{i}$ is the difference between observed and predicted core temperature response at each time point $\left({ }^{\circ} \mathrm{C}\right)$ and $n$ is the number of time points examined with an interval of 10-min used. The prediction was considered valid if the RMSD fell below the SD of the observed values [33].

Non-parametric Bland-Altman plots were also used to determine the level of agreement [37] between the observed and predicted temperatures for the 6-CTM using $\pm 0.4{ }^{\circ} \mathrm{C}$ as a qualitative physiological threshold for assessment for $T_{\text {pill }}$ and $\pm 1.0{ }^{\circ} \mathrm{C}$ for skin temperature. This threshold is twice the anticipated standard deviation for core temperature [38] which accounts for unique and additive response variability likely to occur with experimental perturbations. Smaller differences are therefore within the acceptable noise of the measurement and were considered of marginal importance independent of the $p$ value. This procedure allows data evaluation against an evidentiary standard other than zero, similar to equivalence testing [39]. Data for Bland-Altman plots were binned into three 3-h time blocks to examine differences between observed and predicted values over time.

\section{Results}

\section{Heart rate, pill, and skin temperatures} Study 1

Figure 1 shows the HR response, over 1-h periods, during the first training exercise $(n=18)$. During the physical activity portion of each day, the mean heart rate was $130 \pm 2$ beats per min (bpm), or $\sim 65 \%$ age-predicted maximal heart rate. Between daily bouts of ski marching, the HR averaged $\sim 88 \mathrm{bpm}$, with values between 70 and $80 \mathrm{bpm}$ during sleep. During the prolonged periods of skiing, the mean $T_{\text {chest }}$ was $34.1 \pm 0.7^{\circ} \mathrm{C}(n=18)$, with a slight elevation during the rest periods $\left(35.5^{\circ} \mathrm{C}\right)$. Figure 1 also shows the $T_{\text {pill }}$ response every hour over the course of the ski march $(n=10) . T_{\text {pill }}$ averaged $37.5 \pm 0.1^{\circ} \mathrm{C}$ during the exercise periods, reaching a nadir $\left(36.27^{\circ} \mathrm{C}\right) \sim 5 \mathrm{~h}$ into each rest period. The mean maximal $T_{\text {pill }}(n=10)$ during skiing was $38.2 \pm 0.2{ }^{\circ} \mathrm{C}$ (highest value $=38.4{ }^{\circ} \mathrm{C}$ ). At rest, the mean minimal $T_{\text {pill }}$ was $36.0 \pm 0.3$ (lowest value $=35.5^{\circ} \mathrm{C}$ ).

\section{Study 2}

The HR response every hour over the study period is depicted in Fig. $2(n=10)$. The overall HR was highest for the first day of the ski march and bivouac ( 140 bpm). During subsequent days, the HR was $\sim 120-130 \mathrm{bpm}$, similar to that observed in study 1 . During the rest periods, HR decreased to $60 \mathrm{bpm}$.

Figure 2 shows the $T_{\text {pill }}$ response over the training period $(n=10)$. The mean $T_{\text {pill }}$ was highest during the first movement, paralleling that of HR. The highest mean $T_{\text {pill }}$ during this first movement was $38.07^{\circ} \mathrm{C}$. During the rest periods, the average $T_{\text {pill }}$ fell to $\sim 36.0-36.2{ }^{\circ} \mathrm{C}$, with the lowest values observed on the third night, when the soldiers were confined to their tents due to a storm. The lowest individual $T_{\text {pill }}$ during this time was $35.6{ }^{\circ} \mathrm{C}$. $T_{\text {ch- }}$ est values ranged between 33 and $36^{\circ} \mathrm{C}$, with the highest values obtained when the volunteers were resting in their tents.

Peripheral skin temperatures $\left[T_{\text {fing }}(n=9)\right.$ and $T_{\text {toe }}$ $(n=10)]$ are shown in Fig. 3. During the first 2 days of ski marching, $T_{\text {fing }}$ reached as high as $35^{\circ} \mathrm{C}$. Over the last 2 days of the March, $T_{\text {fing }}$ ranged between 25 and $30{ }^{\circ} \mathrm{C}$. During the rest periods, $T_{\text {fing }}$ was typically between 15 and $20^{\circ} \mathrm{C}$, although during the storm, temperatures fell as low as $6-10{ }^{\circ} \mathrm{C}$. Similar to $T_{\text {fing }}, T_{\text {toe }}$ reached $35^{\circ} \mathrm{C}$ during the first movement. Subsequent $T_{\text {toe }}$ during the ski marches was between 25 and $30^{\circ} \mathrm{C}$. During the rest periods, $T_{\text {toe }}$ was between 15 and $20^{\circ} \mathrm{C}$. $T_{\text {wrist }}(n=5)$ during exercise was $\sim 33{ }^{\circ} \mathrm{C}$; at rest $T_{\text {wrist }}$ was $25-26{ }^{\circ} \mathrm{C}$. $T_{\text {calf }}$ $(n=4)$ fluctuated between 30 and $35^{\circ} \mathrm{C}$ throughout the training exercise.

\section{IREQ and 6-CTM predictive model}

During the 2nd day of ski marching in the second study, the calculated IREQ required to maintain thermal balance at a normal mean body temperature ranged from 2.0 to 2.6 clo; the DLE was calculated to be greater than $8 \mathrm{~h}$.

Figure 4 shows the observed values over the $10-\mathrm{h}$ time period compared to the predicted values using the 6-CTM. The SD and RMSD for each trial are presented in Table 2.

Using the RMSD criterion, the 6-CTM fits the data for chest temperature, but RMSD was higher than the SD for $T_{\text {pill }}$ and $T_{\text {calf }}$. To better evaluate the practical importance of the differences between predicted and measured 

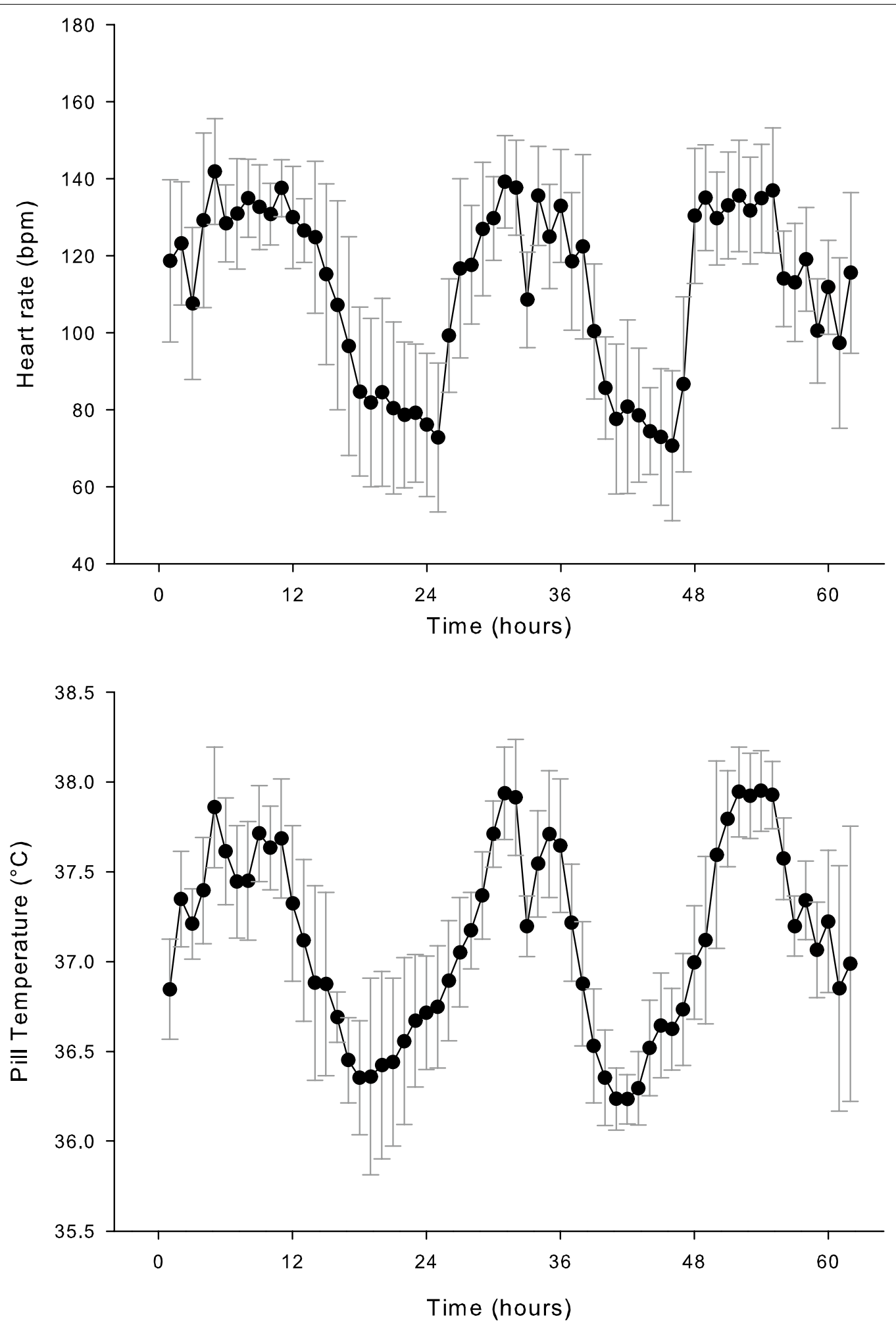

Fig. 1 Heart rate (HR) and pill temperature ( $\left.T_{\text {pill }}\right)$ vs. time during 3-day Arctic ski march (study 1). Data are mean \pm S.D. $\left(H R: n=18 ; T_{\text {pill }} n=10\right)$ 

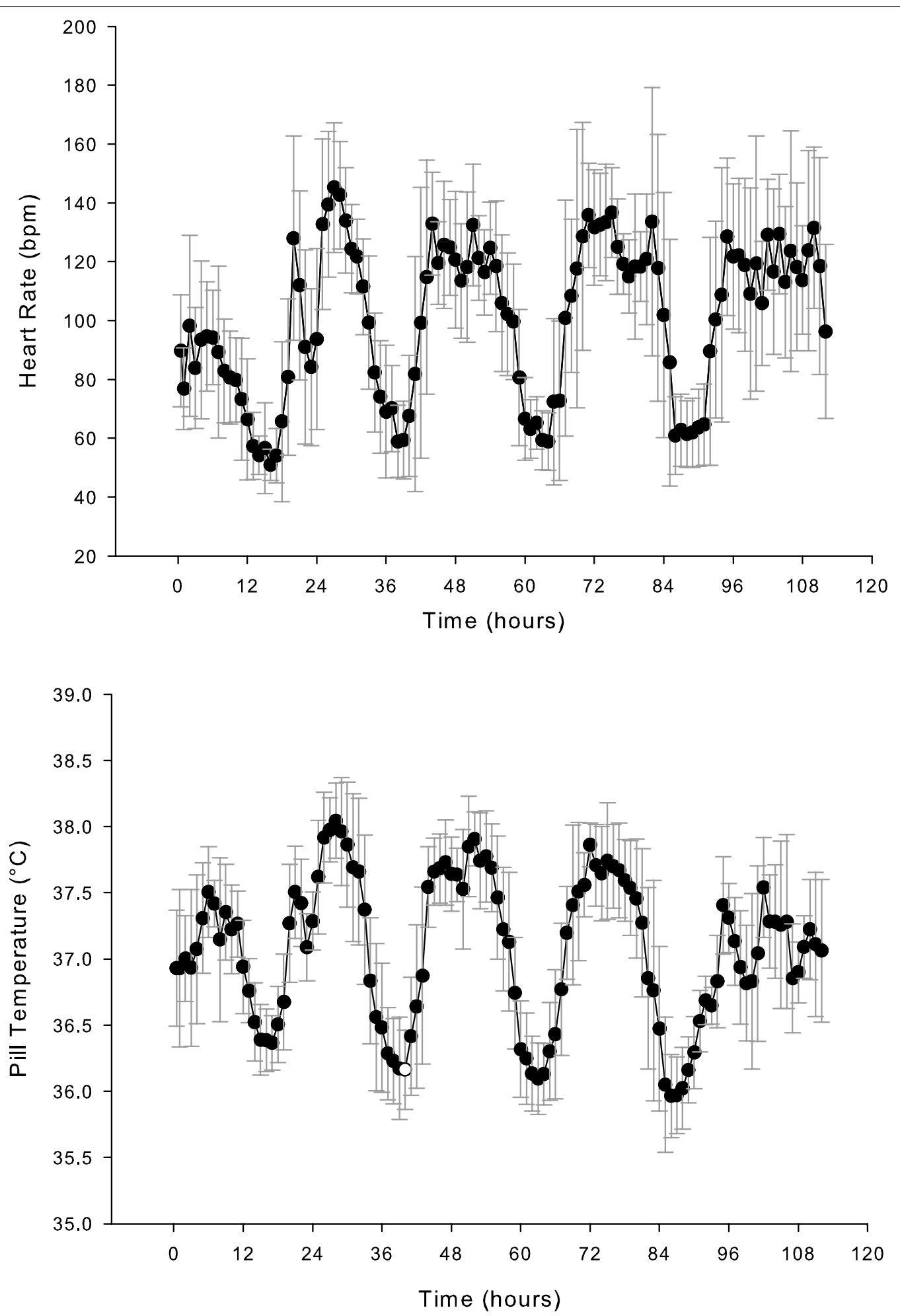

Fig. 2 Heart rate and pill temperature vs. time during 4-day Arctic ski march (study $2, n=10$ ). Data are mean \pm S.D

values, non-parametric Bland-Altman plots were constructed for each trial to determine what percentage of the predicted values fell within a qualitative threshold of importance $\left(0.4{ }^{\circ} \mathrm{C}\right.$ for $T_{\text {pill }}$ and $1.0{ }^{\circ} \mathrm{C}$ for skin temperatures). Figure 5 presents these data over time. For $T_{\text {pill }}, 53 \%$ of the observations fell between $\pm 0.4{ }^{\circ} \mathrm{C}$, with 

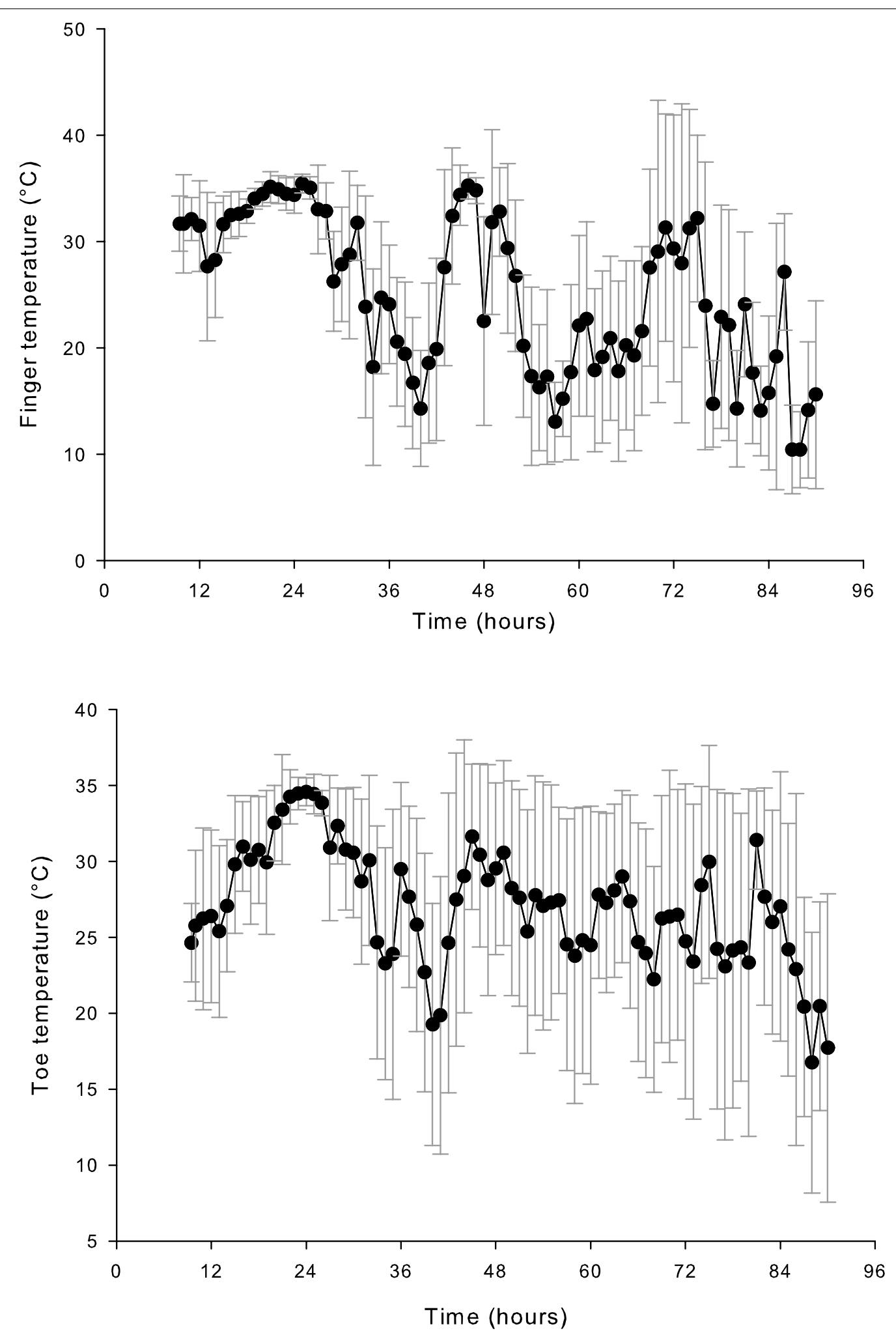

Fig. 3 Finger ( $\left.T_{\text {finger }}\right)$ and toe ( $\left.T_{\text {toe }}\right)$ temperatures vs. time during 4-day Arctic ski march (study 2). Data are mean \pm S.D. $\left(T_{\text {finger: }}: n=9 ; T_{\text {toe }}: n=10\right)$ 

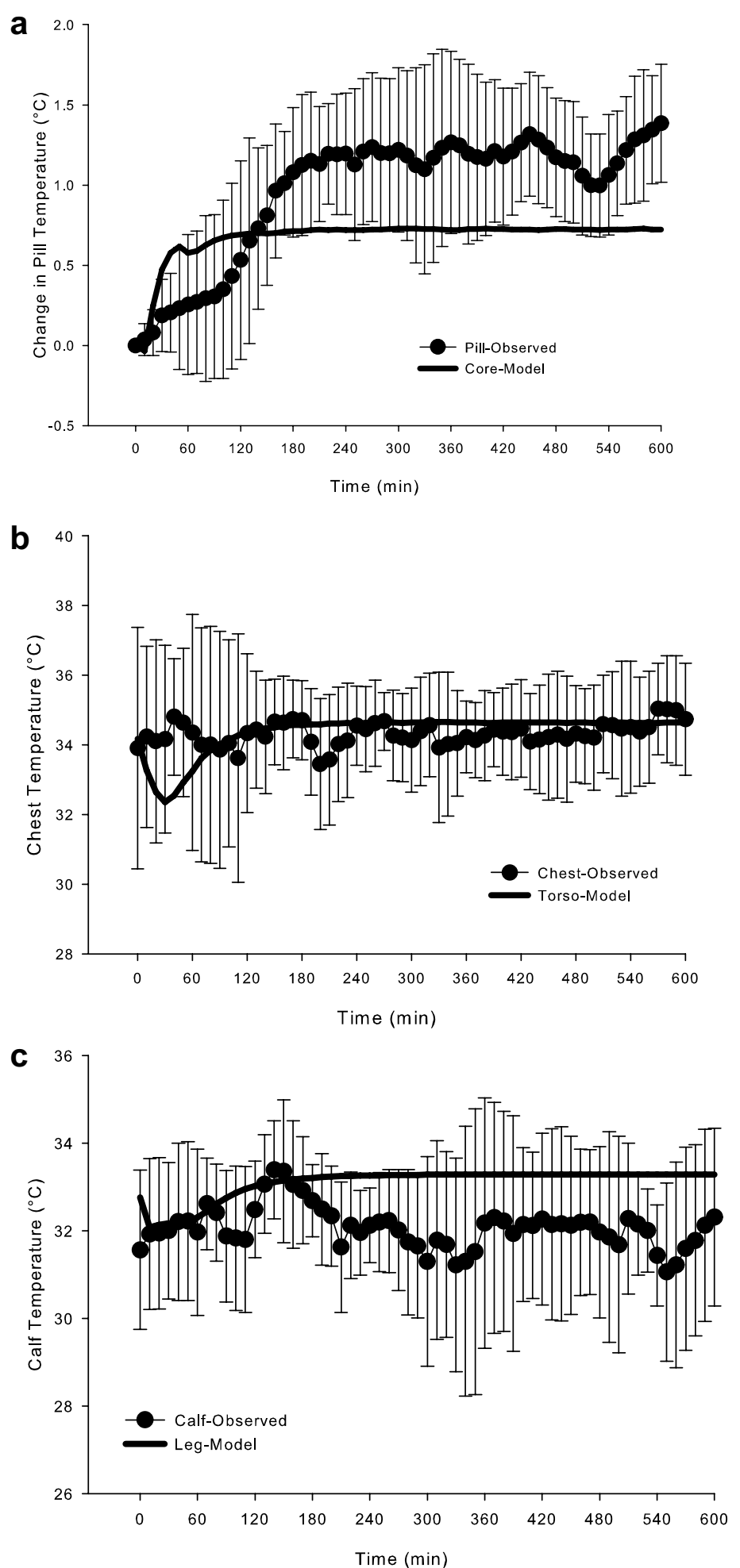

Fig. 4 Observed (mean \pm S.D.) and predicted change in pill (a), chest $(\mathbf{b})$, and calf (c) temperatures vs. time during 10 -h ski march in $-6.1^{\circ} \mathrm{C}$ air temperature. Predicted values were calculated using the 6-CTM thermoregulatory model 
Table 2 Standard deviations and root mean square deviations (RMSD) for 3 temperature sites during 10-h ski march (hours 41-51) in Study 2

\begin{tabular}{lcll}
\hline Measurement & No. of volunteers & Standard deviation & RMSD \\
\hline Pill (Core) & 10 & 0.45 & 0.59 \\
Chest (Torso) & 8 & 1.67 & 1.34 \\
Calf (Leg) & 4 & 1.70 & 1.89 \\
\hline
\end{tabular}

Sites in parentheses denote site for model prediction

the model under-predicting the observed values as time elapsed. For chest temperature, $79 \%$ of the values were between $\pm 1.0{ }^{\circ} \mathrm{C}$, in agreement with the RMSD value, which was lower than the SD. For calf temperature, $58 \%$ of the values were between $\pm 1.0{ }^{\circ} \mathrm{C}$. Two values were clearly over-predicted; these were from the same volunteer.

\section{Discussion}

This study showed that 3-4 days of ski marching in below freezing temperatures elicited only mild cardiovascular and thermal strain, suggesting that the Soldiers' clothing and equipment provided good protection under the environmental and physical conditions studied. Heart rates during skiing averaged $\sim 130$ beats $\mathrm{min}^{-1}$ suggesting that Soldiers worked at $\sim 45 \% \mathrm{VO}_{2 \max }$ for $6-10 \mathrm{~h}$ per day. Deep body temperature, measured with $T_{\text {pill, }}$, reflects this moderate exercise intensity, with values ranging from 37.5 to $38.0{ }^{\circ} \mathrm{C}$. However, during some periods of study 2 , finger temperatures as low as $6-10{ }^{\circ} \mathrm{C}$ were observed during the rest periods, values well below the discomfort $\left(20^{\circ} \mathrm{C}\right)$ and manual dexterity $\left(15^{\circ} \mathrm{C}\right)$ threshold $[4,40,41]$. Likewise, toe temperatures fell to $15-20{ }^{\circ} \mathrm{C}$, well above any potential freezing cold injury risk, but cold enough to elicit discomfort. It is likely that during these periods of low finger and toe temperatures the Soldiers removed their gloves and boots/socks.

The degree of physiological strain is similar to hikes/ military movements conducted over a $3-7.5$ h timeline while carrying external masses of $9.5-31 \mathrm{~kg}[23$, 42, 43]. In these "like" studies, HRs ranged from 110 to 135 beats $\min ^{-1}\left(55-73 \% \mathrm{HR}_{\max }\right)$, similar to that observed in the present study. The self-selected exercise intensities $\left(\sim 35 \mathrm{VO}_{2 \max }\right)$ in our study were also consistent with a 6-day military exercise [44] during which Soldiers carried external mass. Interestingly, this exercise intensity of $35-50 \% \mathrm{VO}_{2 \max }$ exhibited with load carriage is comparable to reports for self-paced or self-selected exercise in temperate conditions without carrying external mass. Ekkekakis [45] summarized the literature for self-selected exercise intensity and showed in the majority of studies across a wide spectrum of exercise and activities of daily living (running, walking, lawn mowing, house cleaning) that people voluntarily choose to exercise between $60-70 \% \mathrm{HR}_{\max }$ and $40-60 \% \mathrm{VO}_{2 \max }$. Adventure races also provide insight into exercise intensities; studies demonstrate that participants in these multi-day events choose intensities at $\sim 40 \% \mathrm{VO}_{2 \max }[46,47]$.

Deep body temperatures $\left(T_{\text {pill }}\right)$ throughout the ski marches were unremarkable, and similar to other occupational scenarios in a variety of environmental conditions. Virokannas [13] presented histograms of core temperature during outside work comprising light, moderate, and heavy work in cold environmental conditions $\left(-10\right.$ to $\left.5^{\circ} \mathrm{C}\right)$. He found that during moderate work $(340 \mathrm{~W})$, rectal temperature $\left(T_{\mathrm{re}}\right)$ was primarily distributed around $37.5{ }^{\circ} \mathrm{C}$, while heavy work $(420 \mathrm{~W})$ caused $T_{\text {re }}$ to primarily range between 37.5 and $38^{\circ} \mathrm{C}$. Ainslie et al. [42] observed $T_{\text {re }}$ values between 37.5 and $38{ }^{\circ} \mathrm{C}$ during $7.5 \mathrm{~h}$ of hill walking (9.5 kg external load carriage) when consuming $3000 \mathrm{kcal}$ (about a $1700 \mathrm{kcal}$ deficit). Similarly, Morabito et al. [23] reported pill temperatures of $\sim 38{ }^{\circ} \mathrm{C}$ after a $12-\mathrm{km}$ winter movement in $3 \mathrm{~h}$, about a $1{ }^{\circ} \mathrm{C}$ increase from rest. Sleeping deep body temperatures in the current study were similar to that observed during a 54-h physically intense, energy intake-restricted field training exercise in warmer ambient conditions [15], indicating that the insulation from clothing, sleeping bags, and shelter was adequate to protect against freezing injury during the two winter training exercises.

Peripheral skin temperatures, as would be expected from laboratory studies, changed as a function of exercise and rest cycles [12, 48, 49], with the highest values occurring during activity and decreasing during rest, occasionally falling below the dexterity performance threshold $\left(15^{\circ} \mathrm{C}\right)$. Similar findings have also been observed during military field training exercises. $T_{\text {toe }}$ during guard duty (rest) were $15.4{ }^{\circ} \mathrm{C}$ and increased to $31.2^{\circ} \mathrm{C}$ during hiking at an $\mathrm{O}_{2}$ uptake of 1-1.5 L/min [9]. Similarly, Rissanen et al. [8] showed during a 12-day field exercise $\left(T_{\text {air: }}:-20\right.$ to $2{ }^{\circ} \mathrm{C}$ ), combat activities eliciting a HR of $\sim 102 \mathrm{bpm}$ raised $T_{\text {fing }}$ to $23.1^{\circ} \mathrm{C}$, compared to a $T_{\text {fing }}$ of $19.8^{\circ} \mathrm{C}$ when HR was $89 \mathrm{bpm}$. Unlike in the Mejkavic study, there were no differences in $T_{\text {toe }}\left(28.8^{\circ} \mathrm{C}\right)$ between activity levels. In quite disparate occupational settings (railyard workers, surveying, construction, patrol skiing) in subarctic Finland [50], finger temperatures averaged $20-28{ }^{\circ} \mathrm{C}$, with minimum values of $6-10{ }^{\circ} \mathrm{C}$, similar to the observations in the current study.

The calculated IREQ values ranged from 2.0 to 2.6 clo. This was due to the moderate metabolic heat production values $(\sim 400 \mathrm{~W})$ caused by skiing. Thus, the insulation provided by the cold-weather uniform $(2.75 \mathrm{clo})$ was more than adequate to prevent a fall in deep body temperature. Indeed, during the ski marches, pill temperature increased to mean values of $37.5-38{ }^{\circ} \mathrm{C}$ 

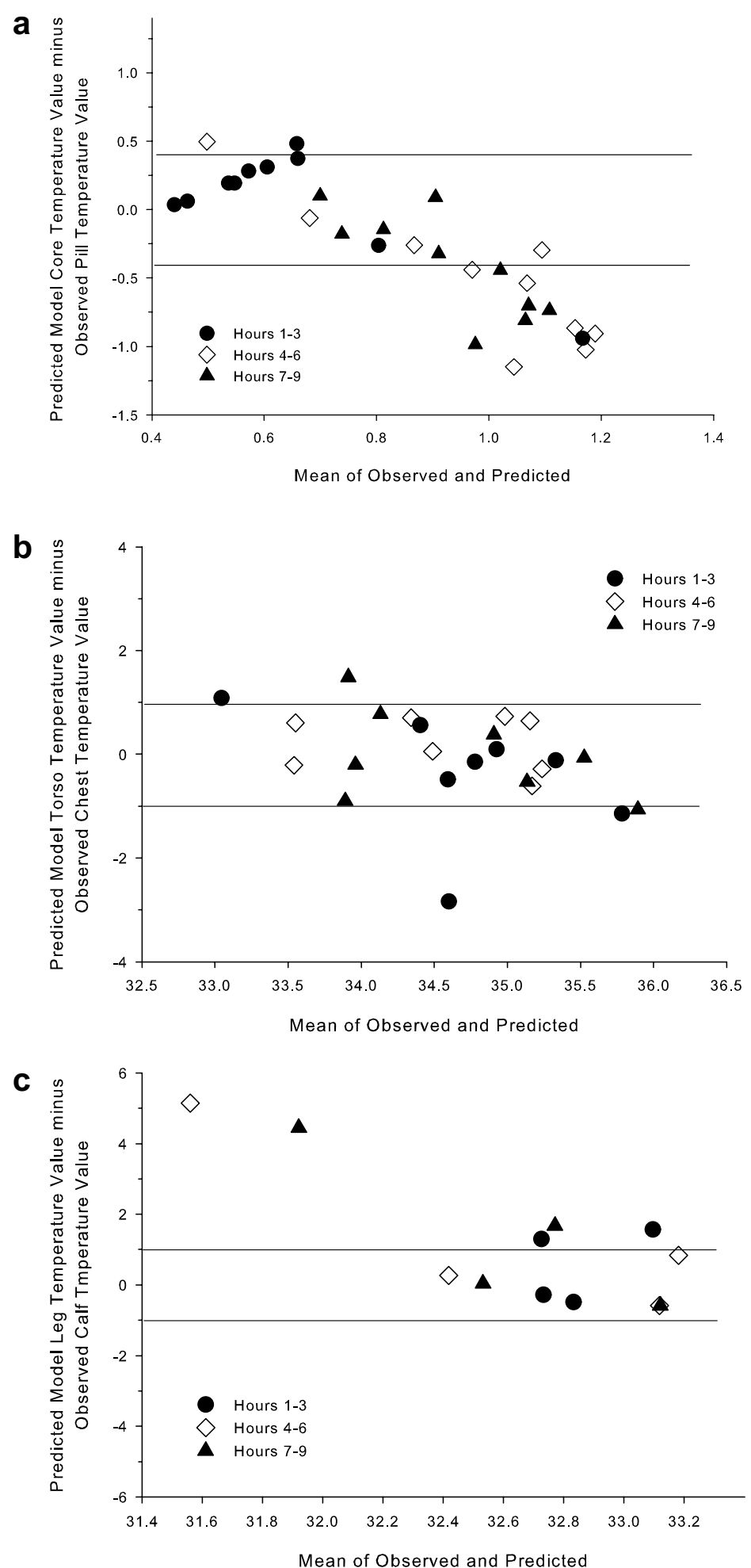

Fig. 5 Bland-Altman plots for the change in change in pill (a), chest (b), and calf (c) temperatures using the 6-CTM thermoregulatory model. Lines shown are the qualitative thresholds $\left( \pm 0.4^{\circ} \mathrm{C}\right.$ for pill temperature; $\pm 1.0^{\circ} \mathrm{C}$ for skin temperatures) for prediction agreement 
throughout the long exercise period. The DLE reflected these deep body temperatures by calculating work limits that extended beyond $8 \mathrm{~h}$. Morabito et al. [23] completed an extensive evaluation of the IREQ during a winter military exercise (12-km hike in $3 \mathrm{~h}$ ). They found that the estimated neutral IREQ during the hike was $\sim 50 \%$ lower $(1.6 \mathrm{clo})$ in 5 out of the 6 soldiers than what was worn (3 clo). Not surprisingly deep body temperature increased by $1{ }^{\circ} \mathrm{C}$. A field validation study concluded that the IREQ does not predict needed clothing insulation as well during relatively high-intensity work [51]. Although the required insulation was adequate in the current and previous studies, one concern is that the increase in deep body temperature can stimulate sweating, and if clothing layers are not adequately managed, can potentially compromise insulation. One limitation of IREQ/DLE is that predicted peripheral temperatures are not included in determining risk susceptibility or work time. Adding thermal models that predict finger/ toe temperatures $[52,53]$ to the IREQ would provide useful information for determining overall cold injury risk susceptibility and enable greater precision for coldweather guidance.

Comparisons between observed values for $T_{\text {pill }}, T_{\text {ch- }}$ est, and $T_{\text {calf }}$ and predicted values for $T_{\text {core, }}, T_{\text {torso }}$, and $T_{\text {leg, }}$, respectively, using the 6-CTM are one of the first reported comparisons made during exercise in cold air at temperatures below freezing; a recent paper compared the Fiala thermophysiological model to values obtained during walking at $60 \% \mathrm{VO}_{2 \text { peak }}$ in $10{ }^{\circ} \mathrm{C}$ air [54]. Observed $T_{\text {chest }}$ values were best fit by the 6-CTM, whereas both $T_{\text {pill }}$ and $T_{\text {calf }}$ had RMSD values above the SD and $50-60 \%$ of the values within the accepted criterion using non-parametric Bland-Altman plots. Core temperature was predicted within the $\mathrm{SD}$ and the $0.4{ }^{\circ} \mathrm{C}$ criterion for the first $3 \mathrm{~h}$ of exercise in $-6.2{ }^{\circ} \mathrm{C}$ air (wind chill temperature index of $-14{ }^{\circ} \mathrm{C}$ ), but under-predicted during the rest of the ski march for Day 2. Predicted $T_{\text {calf }}$, although with a higher RMSD than S.D., was within the measured SD (Fig. 4). A limitation in the present study is the estimation of metabolic rate from prediction equations; measuring oxygen uptake during these field conditions would enable more accurate validation of thermal models during exercise in cold air. As well, model validation in these conditions will allow better predictions of the effects of clothing on core and skin temperatures. Similar to the IREQ, a limitation of the 6-CTM is that it does not predict peripheral finger and toe temperatures. This addition to the thermal model would enable it to be used for predicting the peripheral areas most susceptible to freezing cold injury for use in developing coldweather guidance.

\section{Conclusions}

In summary, 3-4 days of ski marching during winter field training exercises in the Arctic elicits moderate cardiovascular and thermal (deep body and torso skin temperature) strain when daily energy intake is 3300-3800 kcals lower than daily energy expenditure. The greatest risk to Soldiers during these types of military exercises is a decrease in peripheral temperatures (finger, toe) that can possibly impair manual dexterity and increase thermal discomfort levels. These characterizations of cardiovascular and thermal strain during military cold-weather operations allow for improved recommendations to be made in an attempt to mitigate potential cold injury risk that could compromise physical performance and military readiness. Predictive thermal modeling demonstrated moderate agreement between observed and predicted values for deep body and skin temperatures. Adding finger and toe temperature predictive capabilities to the IREQ and 6-CTM would increase their ability for providing guidance for cold injury risk prevention.

\section{Abbreviations \\ 6-CTM: 6-cylinder thermoregulatory model; $\mathrm{CHO}$ : carbohydrate supplementa- tion group; CON: control group; DLE: duration limited exposure; EE: energy expenditure; El: energy intake; HR: heart rate; IREQ: insulation required; PRO: protein supplementation group; RMSD: root mean square deviation; SD: standard deviation; $T_{\text {calf }}$ : calf skin temperature; $T_{\text {chest }}$ : chest skin temperature; $T_{\text {fing: }}$ : finger skin temperature; $T_{\text {pill: }}$ gastrointestinal pill temperature; $T_{\text {toe }}$ : toe skin temperature; $T_{\text {re }}$ : rectal temperature; $T_{\text {wrist }}$ : wrist skin temperature; $\mathrm{VO}_{2 \text { max }}$ : maximal oxygen uptake.}

\section{Authors' contributions}

All authors have made substantial intellectual contributions to this complex field study and manuscript. SP, JC, SM, AY, JK, LM, and SJ conceived the study, led the study design, revised data analysis, and helped in writing the draft and final manuscript; MS, AK, and JB provided support in data collection, completed the data analysis, prepared figures, and aided in writing the manuscript, NM coordinated both study iterations and provided support in data collection; XX, HT, PS, and YG provided support for data collection and assessment, revised data analysis, and aided in writing the manuscript. All authors read and approved the final manuscript.

\section{Author details}

${ }^{1}$ United States Army Research Institute of Environmental Medicine, 10 General Greene Avenue, Bldg 42, Natick, MA 01760, USA. ${ }^{2}$ Norwegian Defence Research Establishment, Kjeller, Norway. ${ }^{3}$ General Defence Material/Catering and Combat Feeding Section, Norwegian Navy, Rodskferveien, Norway.

\section{Acknowledgements}

The authors thank the soldiers that participated in this research experiment and the command and training staffs at the Garrisons in Sør-Varanger (Kirkenes, Norway) and Skjold (Overbygd, Norway) for their support of this study.

The investigators adhered to the policies for protection of human subjects as prescribed in Army Regulation 70-25, and the research was conducted in adherence with the provisions of 32 CFR part 219. The opinions or assertions contained herein are the private views of the authors and are not to be construed as official or as reflecting the views of the Army or the Department of Defense. Any citations of commercial organizations and trade names in this report do not constitute an official Department of the Army endorsement of approval of the products or services of these organizations. 


\section{Competing interests}

The authors declare that they have no competing interests.

\section{Ethics approval and consent to participate}

This study was approved by the Institutional Review Board at the US Army Research Institute of Environmental Medicine (Natick, MA, USA) and the Regional Committees for Medical and Health Research Ethics (Oslo, NO).

\section{Publisher's Note}

Springer Nature remains neutral with regard to jurisdictional claims in published maps and institutional affiliations.

Received: 3 April 2017 Accepted: 28 August 2017

Published online: 06 September 2017

\section{References}

1. Castellani JW, Young AJ, Ducharme MB, Giesbrecht GG, Glickman EL, Sallis RE. Prevention of cold injuries during exercise. Med Sci Sports Exerc 2006;38:2012-29

2. Freund BJ, Sawka MN. Influence of cold stress on human fluid balance. In: Marriott BM, Carlson SJ, editors. Nutritional needs in cold and in highaltitude environments. Washington, DC: National Academy Press; 1996. p. $161-79$

3. Pandolf KB, Haisman MF, Goldman RF. Metabolic energy expenditure and terrain coefficients for walking on snow. Ergonomics. 1976;19:683-90.

4. Castellani JW, Tipton MJ. Cold stress effects on exposure tolerance and exercise performance. Compr Physiol. 2016;6:443-69.

5. Castellani JW, Young AJ, Kain JE, Rouse A, Sawka MN. Thermoregulation during cold exposure: effects of prior exercise. J Appl Physiol. 1999;87:247-52

6. Castellani JW, Young AJ, DeGroot DW, Stulz DA, Cadarette BS, Rhind SG, et al. Thermoregulation during cold exposure after several days of exhaustive exercise. J Appl Physiol. 2001:90:939-46.

7. Castellani JW, Sawka MN, Young AJ, DeGroot DW. Cold thermoregulatory responses following exertional fatigue. Front Biosci. 2010;15:854-65.

8. Rissanen S, Rintamäki H, Oksa J, Makinen T, Peitso A. Peripheral skin temperatures during 12 days military manoeuvre in winter conditions. In: Mekjavic IB, Kounalakis SN, Taylor NAS, editors. International conference environmental ergonomics. Piran, Slovenia; 2007: 601-604.

9. Mekjavic IB, Kocjan N, Vrhovec M, Golja P, House C, Eiken O. Foot temperatures and toe blood flow during a winter hike and guard duty. In: Prevention of cold injuries. NATO: Neuilly-sur-Seine, France; 2005: 5-1-5-4.

10. Weller AS, Millard CE, Stroud MA, Greenhaff PL, Macdonald IA. Physiological responses to cold stress during prolonged intermittent low- and high-intensity walking. Am J Physiol. 1997;272:R2025-33.

11. Weller AS, Millard CE, Stroud MA, Greenhaff PL, Macdonald IA. Physiological responses to a cold, wet, and windy environment during prolonged intermittent walking. Am J Physiol. 1997;272:R226-33.

12. Makinen TT, Gavhed D, Holmer I, Rintamäki H. Effects of metabolic rate on thermal responses at different air velocities in $-10^{\circ} \mathrm{C}$. Comp Biochem Physiol. 2001;128:759-68.

13. Virokannas $\mathrm{H}$. Thermal responses to light, moderate and heavy daily outdoor work in cold weather. Eur J Appl Physiol. 1996;72:483-9.

14. Rissanen S, Rintamäki H. Cold and heat strain during cold-weather field training with nuclear biological, and chemical protective clothing. Mil Med. 2007;172:128-32.

15. Castellani JW, DeLany JP, O'Brien C, Hoyt RW, Santee WR, Young AJ. Energy expenditure in men and women during $54 \mathrm{~h}$ of exercise and caloric restriction. Med Sci Sports Exerc. 2006;38:894-900.

16. Young AJ, Castellani JW, O'Brien C, Shippee RL, Tikuisis P, Meyer LG, et al. Exertional fatigue, sleep loss, and negative energy balance increase susceptibility to hypothermia. J Appl Physiol. 1998;85:1210-7.

17. Holmer I. Assessment of cold stress in terms of required clothing insulation-IREQ. Int J Indust Ergon. 1988;3:159-66.

18. ISO. Evaluation of cold environments-Determination of required clothing insulation (IREQ). TR 11079. Geneva: International Organization for Standardization; 1993.
19. Xu X, Werner J. A dynamic model of the human/clothing/environment system. Appl Human Sci. 1997;16:61-75.

20. Xu X, Tikuisis P. Thermoregulatory modeling for cold stress. Compr Physiol. 2014;4:1057-81.

21. Oliveira AVM, Gaspar AR, Raimundo AM, Quintela DA. Evaluation of occupational cold enviroments: field measurements and subjective analysis. Ind Health. 2014:52:262-74

22. Oliveira AVM, Gaspar AR, Quintela DA. Occupational exposure to cold thermal environments: a field study in Portugal. Eur J Appl Physiol. 2008;104:207-14

23. Morabito M, Pavlinic DZ, Crisci A, Capecchi V, Orlandini S, Mekjavic IB. Determining optimal clothing ensembles based on weather forecasts, with particular reference to outdoor winter military activities. Int J Biometeorol. 2011;55:481-90.

24. Castellani JW, O'Brien C, Tikuisis P, Sils IV, Xu X. Evaluation of two cold thermoregulatory models for prediction of core temperature during exercise in cold water. J Appl Physiol. 2007;103:2034-41.

25. Tikuisis P, Gonzalez RR, Pandolf KB. Prediction of human thermoregulatory responses and endurance time in water at 20 and $24^{\circ} \mathrm{C}$. Aviat Space Environ Med. 1988:59:742-8.

26. Margolis LM, Murphy NE, Martini S, Spitz MG, Thrane I, McGraw SM, et al. Effects of winter military training on energy balance, whole-body protein balance, muscle damage, soreness, and physical performance. Appl Physiol Nutr Metab. 2014;39:1395-401.

27. Margolis LM, Murphy NE, Martini S, Gundersen Y, Castellani JW, Karl JP, et al. Effects of supplemental energy on protein balance during 4-day arctic military training. Med Sci Sports Exerc. 2016:48:1604-12.

28. Pandolf KB, Givoni B, Goldman RF. Predicting energy expenditure with loads while standing or walking very slowly. J Appl Physiol. 1977;43:577-81.

29. Taylor NAS, Lewis MC, Notley SR, Peoples GE. A fractionation of the physiological burden of the personal protective equipment worn by firefighters. Eur J Appl Physiol. 2012:112:2913-21.

30. Soule RG, Goldman RF. Energy cost of loads carried on the head, hands, or feet. J Appl Physiol. 1969:27:687-90.

31. Dorman LE, Havenith $G$. The effects of protective clothing on energy consumption during different activities. Eur J Appl Physiol. 2009;105:463-70.

32. Teitlebaum A, Goldman RF. Increased energy cost with multiple clothing layers. J Appl Physiol. 1972;32:743-4

33. Xu X, Tikuisis P, Gonzalez RR, Giesbrecht GG. Thermoregulatory model for prediction of long-term cold exposure. Comput Biol Med. 2005:35:287-98.

34. Stolwijk JAJ, Hardy JD. Control of body temperature. In: Lee DHK, editor Handbook of physiology: reactions to environmental agents. Bethesda: American Physiological Society; 1977. p. 45-68.

35. Werner J, Webb P. A six-cylinder model of human thermoregulation for general use on personal computers. Ann Physiol Anthrop. 1993;12:123-34.

36. Haslam RA, Parson KC. Using computer-based models for predicting human thermal responses to hot and cold environments. Ergonomics. 1994:37:399-416.

37. Bland JM, Altman DG. Measuring agreement in method comparison studies. Stat Meth Med Res. 1999:8:135-60.

38. Consolazio CF, Johnson RE, Pecora LJ. Physiological variability in young men. In: Consolazio CF, Johnson RE, Pecora LJ, editors. Physiological measurements of metabolic functions in man. New York: McGraw Hill Book Co.; 1963. p. 453-80

39. Ebbut AF, Frith L. Practical issues in equivalence trials. Stat Med. 1998;17:1691-701.

40. Havenith G, Heus R, Daanen HAM. The hand in the cold, performance and risk. Arctic Med Res. 1995;54:37-47.

41. Heus R, Daanen HAM, Havenith G. Physiological criteria for functioning of hands in the cold. Appl Ergonom. 1995;26:5-13.

42. Ainslie PN, Campbell IT, Frayn KN, Humphreys SM, Maclaren DPM, Reilly T. Physiological, metabolic, and performance implications of a prolonged hill walk: influence of energy intake. J Appl Physiol. 2003:94:1075-83.

43. Fallowfield JL, Blacker SD, Willems MET, Davey T, Layden J. Neuromuscular and cardiovascular responses of Royal Marine recruits to load carriage in the field. Appl Ergonom. 2012;43:1131-7.

44. Myles WS, Eclache JP, Beury J. Self-pacing during sustained, repetitive exercise. Aviat Space Environ Med. 1979;50:921-4. 
45. Ekkekakis P. Let them roam free? Physiological and psychological evidence for the potential of self-selected exercise intensity in public health. Sports Med. 2009;39:857-88.

46. Lucas SJ, Anglem N, Roberts WS, Anson JG, Palmer CD, Walker RJ, et al. Intensity and physiological strain of competitive ultra-endurnce exercise in humans. J Sports Sci. 2008;26:477-89.

47. Lucas SJE, Helge JW, Schutz UHW, Goldman RF, Cotter JD. Moving in extreme environments: extreme loading; carriage versus distance. Extrem Physiol Med. 2016;5:6-19.

48. Gonzalez RR, EndrusickTL, Santee WR. Thermoregulatory responses to cold: effects of handwear with multi-layered clothing. Aviat Space Environ Med. 1998;69:1076-82.

49. Muller MD, Muller SM, Ryan EJ, Bellar DM, Kim CH, Glickman EL. Pain and thermal sensation in the cold: the effect of interval versus continuous exercise. Eur J Appl Physiol. 2011;111:979-87.
50. Anttonen $\mathrm{H}$, Virokannas $\mathrm{H}$. Assessment of cold stress in outdoor work. Arctic Med Res. 1994;53:40-8.

51. Griefahn B. Limits of and possibilities to improve the IREQ cold stress model (ISO/TR 11079). A validation study in the field. Appl Ergon. 2000;31:423-31.

52. Xu X, EndrusickTL, Santee WB, Kolka MA. Simulation of toe thermal responses to cold exposure while wearing protective footwear(No. 200501-2676). SAE Technical Paper; 2005.

53. Shitzer A, Bellomo S, Stroschein LA, Gonzalez RR, Pandolf KB. Simulation of a cold-stressed finger including the effects of wind, gloves, and coldinduced vasodilation. J Biomech Eng. 1998;120:389-94.

54. Martinez N, Psikuta A, Kuklane K, Quesada JIP, Ortiz de Anda RMC, Soriano $\mathrm{PP}$, et al. Validation of the thermophysiological model by Fiala for prediction of local skin temperature. Int J Biometeorol. 2016;60:1969-82.

\section{Submit your next manuscript to BioMed Central and we will help you at every step:}

- We accept pre-submission inquiries

- Our selector tool helps you to find the most relevant journal

- We provide round the clock customer support

- Convenient online submission

- Thorough peer review

- Inclusion in PubMed and all major indexing services

- Maximum visibility for your research

Submit your manuscript at www.biomedcentral.com/submit 